\title{
Use of antibiotics in upper respiratory infections on patients under 16 years old in private ambulatory medicine
}

\author{
Ingris Peláez-Ballestas, MD,(1) Adolfo Hernández-Garduño, MD, MSc, (1) \\ José Luis Arredondo-García, MD, (2) Jose Luis Viramontes-Madrid, MD, MSc, ${ }^{(3)}$ Artemisa Aguilar-Chiu, MD.(4)
}

\begin{abstract}
Peláez-Ballestas I, Hernández-Garduño A, Arredondo-García JL, Viramontes-Madrid JL, Aguilar-Chiu A. Use of antibiotics in upper respiratory infections on patients under 16 years old in private ambulatory medicine.

Salud Publica Mex 2003;45:159-164.

The English version of this paper is available too at: http://www.insp.mx/salud/index.html
\end{abstract}

\begin{abstract}
Objective. To assess antibiotic use for upper respiratory infections (URI) treatment on patients under 16 years-old who are beneficiaries of a pre-paid health care scheme. Material and Methods. A database containing the record of all the medical prescriptions for URI treatment, from May 1997 to April 1998 was analyzed. Patients were under 16 years old and had been diagnosed with common colds, pharyngitis, bronchitis, sinusitis, otitis, and other unspecified upper respiratory tract infections. Three hundred and fiftyone physicians of seven different specialties who attended 25300 beneficiaries wrote such prescriptions. Results. A total of 30889 assorted medications were prescribed to 5533 patients with the above diagnoses. Antibiotics were prescribed for $77.5 \%$ of all diagnoses, ranging from $58 \%$ for pharyngitis to $91 \%$ for laryngitis. The most frequently used antibiotics were: penicillin, cephalosporins, and macrolides. Conclusions. This study presents the information of antibiotics prescription practices for URI in a pre-paid health plan in Mexico. These findings may be used to support specific campaigns for rational use of antibiotics among children attended at private ambulatory health care practices. The English version of this paper is available too at: http:// www.insp.mx/salud/index.html
\end{abstract}

Key words: antibiotics/therapeutic use; respiratory tract infections; child; adolescence; prescriptions, drug; Mexico
Peláez-Ballestas I, Hernández-Garduño A,

Arredondo-García JL, Viramontes-Madrid JL, Aguilar-Chiu A. Uso de antibióticos en infecciones de vías respiratorias altas de niños atendidos en consulta externa privada.

Salud Publica Mex 2003;45:159-164.

El texto completo en inglés de este artículo también está disponible en: http://www.insp.mx/salud/index.html

\section{Resumen}

Objetivo. Evaluar el uso de antibióticos para tratar las infecciones de vías respiratorias altas (IVRA) en pacientes menores de 16 años con derecho a un sistema médico prepagado privado. Material y métodos. De mayo de 1997 a abril de 1998 se analizó una base de datos de todas las recetas médicas para tratamiento de IVRA. Los pacientes eran menores de edad con diagnósticos de resfriado común, faringitis, bronquitis, sinusitis, otitis o de otras IVRA no especificadas. Las recetas fueron hechas por $35 \mathrm{I}$ médicos de siete especialidades, que atendieron a 25300 beneficiarios. Resultados. Fueron prescritos 30889 tipos de medicamentos a 5533 pacientes con los diagnósticos mencionados. Se recetaron antibióticos para $77.5 \%$ de todos los diagnósticos, desde $58 \%$ para faringitis hasta $91 \%$ para laringitis. Los antibióticos recetados más frecuentemente fueron: penicilina, cefalosporinas, y macrólidos. Conclusiones. Este estudio presenta la información sobre las prácticas prescriptivas médicas para IVRA en una institución de atención médica privada en México. Los hallazgos de este estudio pueden ser utilizados para apoyar campañas específicas a favor del uso racional de antibióticos en niños atendidos en los sistemas privados de consulta externa. El texto completo en inglés de este artículo también está disponible en: http://www.insp.mx/salud/index.html

Palabras clave: antibióticos/uso terapéutico; infecciones del tracto respiratorio; niño; adolescencia; prescripción de medicamentos; México

Project supported by Medco de México Managed Care.

(I) Departamento de Investigación Clínica, Hospital General de México, México, DF, México.

(2) Investigación Clínica, Instituto Nacional de Pediatría, México, DF, México.

(3) Laboratorios Merck, Merck Sharp \& Dohme de México, México, DF, México.

(4) Investigadora independiente.

Received on: April 26, 2002 - Accepted on: October 24, 2002

Address reprint requests to:Adolfo Gabriel Hernández Garduño. Dirección de Investigación, Hospital General de México, Secretaría de Salud. Dr. Balmis I48, colonia Doctores, 06726 México, DF.

E-mail: hzglob@liceaga.facmed.unam.mx 
$\mathrm{U}$ pper respiratory infections (URI) is the most common infectious pathology on children, often reported in a frequency of 5 to 8 episodes per year in urban areas. ${ }^{1}$ The use of antimicrobials in such cases is a constantly debated topic; in spite of the fact that is largely accepted that these infections are virus related. The high frequency of antibiotic usage on URI is a worldwide issue, ${ }^{1-6}$ always ranking high among the conditions associated with antibiotic prescriptions. ${ }^{7}$

According to the current literature, before prescribing an antibiotic for these infections, a precise diagnosis must precede; such diagnosis shall establish its bacterial origin to prevent the null clinical utility of the drug and a potential risk of increasing bacterial resistance. ${ }^{4}$ This is particularly important in pediatric populations, where the risk of transmission and spread of drug-resistance is high. ${ }^{8}$

The identification of antibiotic-prescribing practices should be the first part of a strategy that would reduce its unnecessary usage and consequences, as already proposed in our setting by Flores-Hernandez et al. ${ }^{9}$

The objective of the study was to assess the antibiotic usage profile for URI among patients under 16 years old, beneficiaries of a pre-paid health care scheme, which is part of the private sector in Mexico. In a pre-paid system, the health care is provided by a private practicing physician and all the expenses are covered by the institution, including drugs. This is the first report of antimicrobial use on URI, based on a database from private practices in Mexico.

\section{Material and Methods}

A retrospective-observational study was carried out using a drug prescription database. Data from URI-related medical visits resulting in at least one prescription medication were included. Subjects were 16-year old patients with a URI antibiotic prescription within one year (May 1997 to April 1998). All data came from an online claims processing system. Data were stored using the software program Oracle 7.3.4 for UNIX.

The database included 25300 (predominantly middle class) subjects, residents of Mexico City. The sample included bank employees (39\%) and their relatives (54\%); retirees $(7 \%), 37.1 \%$ of them were between 0 and 20 years of age, 58\% between 20 and 60, and $4.9 \%$ were older than 60 years. A total of 351 physicians provided medical care to this population on a fee-for-service basis. The seven specialties represented in the database were: General/Family Practice, Pediatrics, Otolaryngology, Surgery, Allergy, and Internal Medicine. Data included the pharmacological history of each subject and a list of all drugs prescribed, along with a record of the prescribed and dispensed doses. Every drug prescribed had a specific coded diagnosis written by the prescribing physician (based on World Health Organization (WHO) 10th International Classification of Disease, ICD-10). ${ }^{10}$ The physician had to assign a specific diagnosis for each drug included (up to three different diagnoses per prescription). The computer system automatically registers the presentation, active ingredient, date supplied, patient's age and gender, prescribing physician, and physician's specialty.

The following variables were analyzed for each patient: a) date; b) patient's age; c) patient's gender; d) active ingredient of prescribed drug; e) drug therapeutic class; f) drug prescribed dose; g) number of days indicated; $h$ ) specialty of the prescribing physician, and i) diagnosis that motivated the prescription (ICD-10 codes). Using ICD-10 codes, patients' diagnoses were selected and grouped as follows: rhinopharyngitis/ common cold (J00), pharyngitis (J02, J02.0, J02.8, J0.9), bronchitis (J20, J20.0, J20.2, J20.8, J20.9, J40), laryngitis (J04), amigdalitis (J03, J03.8, J03.9, J35.0), sinusitis (J01, J01.4, J01.9), otitis (H60.3, H65, H65.9, H66), and other unspecified upper respiratory tract infections (J06, J06.8).

The drug database only provided information about drugs dispensed at pharmacies. More than $90 \%$ of all clinical visits generated at least one single prescription.

Data were analyzed using the STATVIEW 5 Statistical Program for Macintosh and Windows (SAS Institute Inc., Cary, NC). Data are presented as means and standard deviations for continuous variables and as proportions for categorical variables. Age was categorized in five groups: a) less than one year, b) 1 to 2 years, c) 3 to 5 years, d) 6 to 10 years, and e) 11 to 16 years. For each group, the spectrum of drugs used by specialty was analyzed using the $\chi^{2}$ test. Diagnosis under which the prescription was filled, duration and amount of prescribed drug were analyzed using oneway analysis of variance (ANOVA).

\section{Results}

The sample contained 30889 prescriptions filled for patients under 16 years of age. These patients were prescribed at least once under the selected diagnoses during the period of study. By gender, the proportion of participants was similar (48\% males, 52\% females). Most of the population (32.4\%) was in the 6 to 10 yearold age range. The total average of drugs prescribed per patient was 5.6 drugs and varied from 4.6 for the 11 to 16 year-old group, to 6.3 for the 3 to 5 year-old group. These differences were statistically significant (ANOVA, $p<0.001$ ), (Table I).

salud pública de méxico / vol.45, no.3, mayo-junio de 2003 
Table I

Proportion OF PATIENTS AND FiLes PER AGE GROUP, AND MEANS OF FILLS/PATIENTS IN UPPER RESPIRATORY INFECTIONS (URI)*. MEXICO CITY, I 997-I 998

\begin{tabular}{|c|c|c|c|c|c|}
\hline Age group (years) & $<1$ & $1-2$ & $3-5$ & $6-10$ & $11-16$ \\
\hline Proportion of patients ( $n=5533$ ) & 8.2 & 10.9 & 24.7 & 32.4 & 23.8 \\
\hline Proportion of fills $(n=30889)$ & 8.3 & 12.1 & 28.1 & 31.8 & 19.7 \\
\hline Means (SD) of fills/patients ${ }^{\ddagger}$ & $5.6(4.5)$ & $6.2(4.7)$ & $6.3(4.9)$ & $5.4(3.9)$ & $4.6(3.1)$ \\
\hline
\end{tabular}

Pediatricians prescribed (74.2\%) antibiotics more frequently, contrasting with general practitioners $(24.9 \%)$ and other specialties, such as otolaryngology, surgeons and allergy specialists $(0.8 \%)\left(\chi^{2}\right.$ test, $\left.p<0.001\right)$. The use of antibiotics was lower in the younger groups, and this observation was consistent across the different specialties. (Data not showed).

The most common diagnosis was pharyngitis $(41 \%)$, followed by rhinopharyngitis or common cold (24.6\%), amigdalitis (16.3\%), bronchitis $(4.8 \%)$, other unspecified upper respiratory tract infections $(3.6 \%)$, sinusitis $(3.2 \%)$, laryngitis $(3.2 \%)$, and otitis $(3.1 \%)$.

The overall usage frequency of antibiotics in the total sample reached $77.5 \%$, ranging from $58.1 \%$ in patients with diagnosis of pharyngitis, to $91 \%$ in those with laryngitis. From another perspective, $22.5 \%$ of all the patients seen for URI, received and filled a prescription which did not include an antibiotic.

Antibiotic drugs were more frequently prescribed than non-antibiotic drugs (symptomatic), with a 2.1:1 ratio. In general, $31.9 \%$ of all drugs prescribed were antibiotics, which means that 9823 antibiotics were received by the 5533 patients with URI who filled a prescription within the analyzed period (an average of 1.8 antibiotics per patient).

The highest mean of days of treatment with an antibiotic corresponded to sinusitis (8.8), followed by otitis (6.6), bronchitis (6.4), rhinopharyngitis/common cold (6.1), pharyngitis (6.0), upper respiratory tract infections (6), amigdalitis (5.9), and laryngitis (5.5), (Table II).

The five most prescribed antibiotics for all age groups, diagnoses, and medical specialties were: a) Amoxicillin (16.8\%), b) Amoxicillin plus clavulanic acid $(10.7 \%)$, c) Penicillin $(8.5 \%)$, d) clarythromycin $(6.8 \%)$, e) Cephalexine (5.6\%), (Table III).
When these data were analyzed based on diagnosis, differences were found in the type of antibiotics used. For the diagnosis of otitis and sinusitis, the most frequently used antibiotic was amoxicillin plus clavulanic acid, followed by second-generation cephalosporins (cefaclor and cefuroxime). In bronchitis, the most common antibiotic was penicillin, followed by amoxicillin and azithromycin. For laryngitis the most common antibiotic was amoxicillin, followed by sulphametoxazol/trimethroprim, and amoxicillin plus clavulanic acid. For the common cold, the most com-

Table II

ANTIBIOTIC-PRESCRIBING PATTERNS IN A PEDIATRIC POPULATION WITH DIAGNOSIS OF UPPER RESPIRATORY infections (URI). MeXico City, I997-I998

$\begin{array}{cccc} & \text { Percent } & \text { Prescribing } \\ \text { Diagnostic }(I C D-10 \text { codes)* } & \text { Fills } & \text { of } & \text { days } \\ \text { (n) } & \text { antibiotics } & \text { Mean } & (S D)^{\S}\end{array}$

\begin{tabular}{|c|c|c|c|}
\hline Amigdalitis (J03,J03.8,J03.9,J35.0) & 5026 & 73.6 & $5.9(4.5)$ \\
\hline Rhynopharyngitis (common cold) (J00) & 7628 & 71.9 & $6.1(4.7)$ \\
\hline Bronchitis (J20,J20.2,J20.8,J20.9,J20.0,J40) & 1470 & 85.9 & $6.4(5)$ \\
\hline \multicolumn{4}{|l|}{ Upper respiratory tract } \\
\hline infections $(006,06.8)$ & 1117 & 69.1 & $6.0(3.7)$ \\
\hline Laryngitis (J04,J04.2,J04.0,J06.0) & 999 & 91.0 & $5.5(2.9)$ \\
\hline Pharyngitis (J02,J02.8,J02.9,J02.0) & 12624 & 58.1 & $6.0(5.0)$ \\
\hline Sinusitis (J0I,J0I.4,J0I.9) & 1001 & 87.4 & $8.8(8.9)$ \\
\hline Otitis (H60.3,H65, H65.9,H66.9) & 964 & 82.7 & $6.6(5.6)$ \\
\hline
\end{tabular}

* International Statistical Classification of Diseases and Related Health Problems, IOth Revision. Ginebra. World Health Organization. 1992

‡ Calculated dividing the total number of antibiotics/the total number of patients per diagnosis

$\S$ One-Way ANOVA, F-value 38.I I, $p<0.001$ 
Table III

Frequency of ANTIBIOTIC PRESCRIPTIONS.* MeXico City, I997-I998

\begin{tabular}{|c|c|c|}
\hline Rank & Generic drug name & $\%$ \\
\hline I & Amoxicillin & 16.8 \\
\hline 2 & Amoxicillin, clavulanate potassium & 10.7 \\
\hline 3 & Penicillin & 8.5 \\
\hline 4 & Clarithromycin & 6.8 \\
\hline 5 & Cephalexine & 5.6 \\
\hline 6 & Azithromycin & 5.1 \\
\hline 7 & Cefaclor & 5.0 \\
\hline 8 & Sulfamethoxazole/trimethoprim & 4.9 \\
\hline 9 & Erythromycin & 4.3 \\
\hline 10 & Ampicillin & 4.I \\
\hline II & Amoxicillin/bromhexine & 3.8 \\
\hline 12 & Cefadroxil & 3.2 \\
\hline 13 & Cefuroxime & 2.6 \\
\hline 14 & Dicloxacillin & 2.5 \\
\hline 15 & Amoxicillin/ambroxol & 1.9 \\
\hline 16 & Cefixime & 1.4 \\
\hline 17 & Lincomycin & 1.4 \\
\hline 18 & Sultamicillin & 1.3 \\
\hline 19 & Sulfamethoxazole/trimethoprim/guafenesin & 0.9 \\
\hline 20 & Chloramphenicol/hydrocortisone/benzocaine & 0.8 \\
\hline 21 & Loracarbef & 0.8 \\
\hline 22 & Ceftibuten & 0.7 \\
\hline 23 & Propicillin & 0.7 \\
\hline 24 & Cefprozil & 0.6 \\
\hline 25 & Erythromycin, ethylsuccinate sulfisoxazole, acetyl & 0.6 \\
\hline
\end{tabular}

* Note: Only the first 25 antibiotics were included

mon antibiotics prescribed were amoxicillin, penicillin, amoxicillin plus clavulanic acid, and cephalexine.

Forty-five different antibiotics were prescribed. After sorting them by class, they were analyzed. The most frequently prescribed group was penicillin (including aminopenicillins) (52.1\%), followed by cephalosporins $(20.4 \%$, predominantly those belonging to the second generation with $37.4 \%)$, macrolides (17.9\%), and sulphonamides $(6 \%)$.

\section{Discussion}

To our knowledge, this is the first study that analyzes the prescribing pattern of physicians working in a private practice setting in Mexico, where doctors have no drug-selection restrictions.

Worldwide, the frequent use of antibiotics in ambulatory patients with URI is a topic of great epide- miological and economic impact. It was found that 7 out of every 10 pediatric patients with URI received an antibiotic. This frequency of antibiotic usage for URI is higher than that in most of the previous reports, ${ }^{2,3,6}$ suggesting an over-utilization of antibiotics, in contrast with standard practices. ${ }^{9}$ This finding is similar with that reported in the National Health Survey (1994), ${ }^{11}$ where a prescription percentage of $87 \%$ was found in beneficiaries of all ages at private institutions. The frequency of antibiotic usage found in this report might be consistent with the whole private medical practice in Mexico.

Rosenstein et $\mathrm{f}^{2}$ and Gonzalez et $\mathrm{l}^{6}$ both reported that $50 \%$ to $70 \%$ of patients having a common cold are prescribed an antibiotic. This may be due to insistence by the patient to be prescribed antibiotics. ${ }^{12}$

In Mexico, Gutierrez et al ${ }^{3}$ reported $63 \%$ usage of antibiotics for URI in an outpatient rural population covered by a health insurance scheme that provided a $100 \%$ reimbursement for drugs. Libreros et al $l^{4}$ found a similar pattern in $85.5 \%$ of the patients with URI attending the social security system, and $70.4 \%$ in those attending a public health system.

If analysis is limited only to rhinopharyngitis/ common cold cases (J00), the percentage $(71.9 \%)$ is considered high, given the viral etiology of most of these infections. Moreover, it could also contribute to the increasing antimicrobial drug resistance in our setting. ${ }^{4}$

In studies performed in children, Nyquist et a ${ }^{\beta}$ reported $44 \%$ of antibiotic usage in common cold and Schwartz et a ${ }^{13}$ reported $71 \%$. In populations that included adults, Libreros et al ${ }^{4}$ observed $80.4 \%$ of antibiotic usage for the common cold in Mexico, and Mainous et a $l^{5}$ observed $60 \%$. Conversely, Guillemont et al, ${ }_{1}^{14}$ in a study conducted in Europe, reported that only $17 \%$ of common cold cases were given antibiotics.

Among patients with sinusitis and otitis, $87.4 \%$ and $82.7 \%$ were given an antibiotic, respectively, thus meeting standard guidelines. ${ }^{9}$

Considering the reduced group of diagnoses reviewed, the high variability of prescribed antibiotics is of great concern (45 different antibiotics). McCaig and Hughes ${ }^{7}$ reported that their study group of physicians prescribed only 19 different antibiotics to treat URI.

The distribution of antibiotics by therapeutic group showed a high use of cephalosporins (27\%), with a higher proportion of second generation types, a finding consistent with reports elsewhere. ${ }^{5,13}$ The use of penicillin is still important in Mexico. Penicillin was considered as the third therapeutic option in physicians' preferences, with $8.5 \%$ of the total. Gutierrez 
et $a^{\beta}$ and Libreros et a ${ }^{4}$ also observed a high use of penicillin ( $54.8 \%$ and $25.5 \%$, respectively). Nevertheless, it should be considered that the population studied in those reports consisted of social security beneficiaries relying on a Closed Formulary. It is also important to note that the studies were carried out when some of the cephalosporin and aminopenicillinbased antibiotics were not as popular as they currently are. It is interesting that the percentage found in our study for erythromycin (4.3\%) was rather low if compared with that reported by Mexico's social security system (where it is the first antibiotic prescribed in $30.3 \%$ of the population). ${ }^{4}$

Regarding the results observed in different groups of medical specialties, general practitioners tend to prescribe antibiotics more often in younger groups (less than one year), while medical specialists prescribe antibiotics with a lower frequency $(p<0.05)$.

The studies conducted in our setting and those reported from other countries are based on surveys directed to physicians. This might mislead the recording and accuracy of the analyzed information. However, the use of a prescription database -such as the one we use in the present report- can reduce or eliminate possible inaccuracies. Information is taken from an electronic system that records only what is filled from each prescription at the final pharmacy level. Still, it is in itself a potential source of bias. Lezzoni ${ }^{15}$ and Goldberg et $a^{16}$ have stressed the issues surrounding the use of administrative databases to conduct epidemiological and economical research. The database used for this study is conformed by $100 \%$ of the prescriptions filled to the population covered. It is mainly a claims database, yet with a high clinical value for analytic purposes. All the information written by the physician included a specific coded diagnosis for each drug and was electronically collected at the pharmacy level. Retrospective analyses allowed billing providers, included physicians, and planning interventions to improve drug use patterns. Another potential source of bias in our database comes from the non-specific ICD-10 code assignment to each case. This often happens when the physician does not remember or does not have the time to look for a more specific one. This "bias of prescription code" may be an important aspect to evaluate in future studies.

Although this study is an interesting approach to physicians' prescribing practices in our setting, conclusions should be taken cautiously if we consider the study design. The database analyzed did not provide outcome information concerning office visits for URI. Only medical encounters where a prescription was finally filled at the pharmacy were informative. Thus, the percentage of patients with URI who received an antibiotic cannot be accurately related to the actual number of patients with URI attending private ambulatory care. We can only assume overutilization in all patients filling a prescription under the diagnosis of URI, being the ratio of antibiotics to symptomatic drugs of 3.4 to 1 ( $77.5 \%$ of patients receiving an antibiotic compared with $22.5 \%$ who did not). As a result, physicians who tend to prescribe any medications will probably be overrepresented. Therefore, our numbers will only show the comparative prescribing pattern of antibiotics versus other (symptomatic) drugs in URI, and not precisely the general frequency of antibiotic prescribing for this condition. It is important to state however, that for this population, the percentage of visits with no filled prescription is low-independently of the diagnosis-, ranging from 5 to $10 \%$. This finding originated from specific analysis regularly performed for doctors' pay-roll purposes (data on file). We believe that the low number of visits resulting in no medical prescription is mainly due to the reimbursement scheme's nature of the provided service. Most patients in this setting expect a medical prescription after visiting a doctor, and the physician could be responding to an unconscious pressure. When a patient attends with symptoms, as it commonly occurs in URI, the percentage of no drug usage should be even higher. ${ }^{12}$ In addition, URI patients who do not seek medical care may be another potential factor of missing data.

On the other hand, there is another major issue to be considered: patients with a viral URI who develop a bacterial complication. This usually leads to a prescription of antibiotics. Unfortunately, the information reviewed is insufficient to identify such cases and their final impact on our results.

Finally, it should be stated that these claim-processing databases show what medical prescriptions really are, with all their implied failures and bias. What this database contains is what patients really filled at the pharmacy, after seeing a doctor. Nowadays, the utilization of this kind of databases must be considered as an important element in pharmacoepidemiology analyses and a very useful tool to improve the decision-making process in clinical practice.

The present report provides information of prescribing practices in URI related with antibiotics in a pre-paid health plan in Mexico. Results show a clear tendency towards drug over-utilization, and so provide a general framework for similar settings.

The average usage of 1.8 antibiotics per patient with URI (77.5\% of the total patients) could be an overestimate, due to the potential presence of antibiotic 
change in "non-responders", an obvious occurrence in viral-origin URI. The findings are to be used as a support for specific campaigns, towards a judicious use of antibiotics in children in our setting.

\section{Acknowledgments}

The authors wish to thank Ricardo Figueroa-Damian MD, Enrique Segura-Cervantes MD, and Gilberto Castañeda PhD, for their comments, as well as Jorge Rodriguez for data management.

\section{References}

I. Dowell SF, Marcy SM, Phillips WR, Gerber MA, Schwartz B. Principles of judicious use of antimicrobial agents for pediatric upper respiratory tract infections. Pediatrics 1998;101:163-165.

2. Rosenstein N, Phillips WR, Gerber MA, Marcy SM, Schwartz B, Dowell SF. The common cold- principles of judicious use of antimicrobial agents. Pediatrics 1998;101:181-184

3. Gutiérrez G, Martínez MC, Guiscafré H, Gómez G, Peniche A, Muñoz

$O$. Encuesta sobre el uso de antimicrobianos en las infecciones respiratorias agudas en la población rural mexicana. Bol Med Hosp Infant Mex 1986;43:761-768.

4. Libreros V, Guiscafré H, Tomé P, Reyes H, Pérez-Cuevas R, Gutiérrez $\mathrm{G}$ et al. Patrones de prescripción terapéutica en diarrea e infecciones respiratorias agudas en dos instituciones de salud: SS e IMSS. Gac Med Mex 1992;128:505-552.
5. Mainous AG, 3a. ed, Hueston W], Clark JR. Antibiotics and upper respiratory infection: Do some folks think is a cure for the common cold? J Fam Pract 1996;42:357-361.

6. González R, Steiner JF, Merle S. Antibiotic prescribing for adults with colds, upper respiratory tract infections, and bronchitis by ambulatory care physicians. JAMA 1997;278:901-904.

7. McCaig LF, Hughes JM. Trends in antimicrobial drug prescribing among office-based physicians in the United States. JAMA 1995;273:214-219.

8. Nyquist AC,González R, Steiner J, Sande MA. Antibiotics for children with upper respiratory tract infections. JAMA 1998;280:1399-1402.

9. Flores-Hernández S, Trejo y Pérez JA, Reyes-Morales H, Pérez-Cuevas R, Loera-Romo G, Juárez Díaz-González $\mathrm{N}$ et al. Diseño y aplicabilidad de una guía clínica para la atención apropiada en las infecciones respiratorias agudas. Gac Med Mex 1999;135:121-137. 10. World Health Organization. International Statistical Classification of Diseases and Related Health Problems, 10th Revision. Ginebra:WHO, 1992.

I I. Leyva-Flores R, Erviti-Erice J, Kageyama-Escobar M,Arredondo A. Prescripción, acceso y gasto en medicamentos entre usuarios de servicios de salud en México. Salud Publica Mex 1998;40:24-31. 12. Hamm RM, Hicks RJ, Bemben DA. Antibiotics and respiratory infections: Are patients more satisfied when expectations are met? J Fam Pract 1996;43:56-62.

13. Schwartz RH,Freij BJ,Ziai M, Scheridan MJ. Antimicrobial prescribing for acute purulent rhinitis in children:A survey of pediatricians and family practitioners. Pediatr Infect Dis J 1997; 16:185-190

14. Guillemot D, Carbon C, Vauzelle-Kervroedan F, Balkau B, Maison P, Bouvenot $\mathrm{G}$ et al. Inappropriateness and variability of antibiotic prescription among French office-based physicians.J Clin Epidemiol 1998:51:61-68.

15. lezzoni LI.Assessing quality using administrative data. Ann Intern Med 1997; 127:666-674

16. Goldberg R, Kotsanos JG. Panel 3: Methodological issues in conducting pharmacoeconomic evaluations. Retrospective and claims database studies. Value Health 1999;2:82-87. 